\title{
1. そもそも「電極電位」って何？（後編）
}

前回「ここが難しい！Part 3」に書いたと おり ${ }^{1)}$, 「電極電位」は実測不可能な值です が, 参照電極電位との差を取ることにより相 対的な值を得ることができます。今回は，こ のように参照電極の選択によって変わって

しまう電位基準ではなく, 電極自身の物理化 学的性質に基づいた電極電位の表し方を紹 介します。

まず，Hg 電極の時代にときどき用いられ たのが pzc 基準の電極電位 $\left(E_{\mathrm{pzc}}\right)$ です ${ }^{2)}$ 。 pzc とは，ゼロ電荷電位(potential of zero charge) の略で，界面電荷密度 $(\sigma)$ がゼロ，すなわち 電極表面が帯電していないと見なせる状態 の電極電位です。この電位は, $\mathrm{Hg}$ 電極であ れば，表面張力測定などから決定できます。 そこで

$$
E_{\mathrm{pzc}}=E-E_{\sigma=0}
$$

とすれば, 参照電極の選択に依存せず電極電 位を表すことができます 3$)$ 。電極が正に帯電 していれば正の電極電位, 負に帯電していれ ば負の電極電位となるので, イメージしやす く，便利です。この表し方は，かつて電極| 溶液界面の電気二重層を議論するときによ く用いられました。しかし，特異吸着のある 系などでは $E_{\sigma=0}$ が変化してしまうこと, 固 体電極では $E_{\sigma=0}$ の決定そのものが困難（不 可能ではありませんが) などのため, 万能で はありません。

電極表面での酸化還元平衡を左右するの は金属 M 中の自由電子の電気化学ポテンシ ヤル $\tilde{\mu}_{\mathrm{e}}$ なので (Part 2 参照) ${ }^{4)}$ ，これを用い て電極電位を表そうという考え方もありま す。まず，簡単な電気化学セル $\mathrm{T}|\mathrm{S}| \mathrm{M} \mid \mathrm{T}$ ’を考 えます。ここで $\mathrm{S}$ は電解質溶液， M と T は 異なる金属で，T’は $\mathrm{T}$ と同じ金属ですが，右 と左を区別するため右側を T’と書きます。 このセルの端子間電位差 $E_{\mathrm{T}-\mathrm{T}}$ は, 各相の内部 電位 $(\phi)$ を用いると，

$$
\begin{aligned}
E_{\mathrm{T}-\mathrm{T}} & =\phi^{\mathrm{T}^{\prime}}-\phi^{\mathrm{T}} \\
& =\left(\phi^{\mathrm{T}^{\prime}}-\phi^{\mathrm{M}}\right)+\left(\phi^{\mathrm{M}}-\phi^{\mathrm{S}}\right)+\left(\phi^{\mathrm{S}}-\phi^{\mathrm{T}}\right)
\end{aligned}
$$

です。 $\mathrm{M} \mid \mathrm{T}$ 界面は異種金属の接触であり, 両 相での $\tilde{\mu}_{\mathrm{e}}$ は等しくなるので,

$$
\mu_{\mathrm{e}}^{\circ, \mathrm{M}}-F \phi^{\mathrm{M}}=\mu_{\mathrm{e}}^{\circ, \mathrm{T}}-F \phi^{\mathrm{T}^{\prime}}
$$

これを $\phi^{\mathrm{T}^{\prime}}-\phi^{\mathrm{M}}$ について解き，先の式の右辺 第 1 項に代入すると,

$$
E_{\mathrm{T}-\mathrm{T}}=\phi^{\mathrm{M}}-\phi^{\mathrm{S}}-\frac{\mu_{\mathrm{e}}^{\circ, \mathrm{M}}}{F}-\phi^{\mathrm{T}}+\phi^{\mathrm{S}}+\frac{\mu_{\mathrm{e}}^{\circ, \mathrm{T}}}{F}
$$

となります。ここで S. Trasatti の用語による 単極電位(single electrode potential)を 5 )

$$
E_{\text {sing }}^{\mathrm{M}}=\phi^{\mathrm{M}}-\phi^{\mathrm{S}}-\frac{\mu_{\mathrm{e}}^{\circ, \mathrm{M}}}{F}
$$

と定義すれば,

$$
E_{\mathrm{T}-\mathrm{T}}=E_{\mathrm{sing}}^{\mathrm{M}}-E_{\text {sing }}^{\mathrm{T}}
$$

となり， $E_{\mathrm{T}-\mathrm{T}}$ を $2 つ の E_{\mathrm{sing}}$ の差として表すこ とができます。しかしこの $E_{\text {sing }}$ は依然として 測定不可能な量です。

$E_{\text {sing }}$ に少し手を加えることにより，測定可 能な量としたものが絶対電極電位(absolute electrode potential)で，これまでに提案された ものが 3 種類あります5)。まず 1 つめは,

$$
\begin{aligned}
E_{\mathrm{abs}, 1} & =E_{\text {sing }}+\phi^{\mathrm{S}} \\
& =\phi^{\mathrm{M}}-\frac{\mu_{\mathrm{e}}^{\circ, \mathrm{M}}}{F}
\end{aligned}
$$

という定義です。 $E_{\mathrm{abs}, 1}$ は $\tilde{\mu}_{\mathrm{e}}^{\mathrm{M}}$ (すなわち Fermi 準位) を電気量 $(-F)$ で割っただけの単純なも ので，「Fermi 電位」と呼ばれることもありま す。これは, M 中の自由電子を真空の無限遠 へ持ち出すときの仕事を電位に換算した值 に相当します。言い換えれば，電位に換算し た $\mathrm{M}$ の仕事関数 $(W)$ と, $\mathrm{M} の$ 外部電位 $(\psi)$ と の和

$$
E_{\text {abs }, 1}=\frac{W^{\mathrm{M}}}{e}+\psi^{\mathrm{M}}
$$

なので，実測可能です。しかしこの值は，定 義に $\phi^{\mathrm{S}}$ が含まれないので, 本来の「電極電位」 としての意味を失っています。たとえば $E_{\mathrm{abs}, 1}$ を用いて電極表面での酸化還元平衡を記述 しようとすると, 何とも関係づけられない $\phi^{\mathrm{S}}$ が宙に浮いてしまうので, Nernst 式の形で表 すことができなくなってしまいますの。すな わち $E_{\mathrm{abs}, 1}$ は，金属中の自由電子のエネルギ 一だけを表しており，これを「電極電位」と して扱うことには無理があります。 
2つめの絶対電極電位は，以下のように定 義されます。

$$
\begin{aligned}
E_{\mathrm{abs}, 2} & =E_{\text {sing }}+\frac{\mu_{\mathrm{e}}^{\circ, \mathrm{S}}}{F} \\
& =\phi^{\mathrm{M}}-\phi^{\mathrm{S}}-\frac{\mu_{\mathrm{e}}^{\circ, \mathrm{M}}-\mu_{\mathrm{e}}^{\circ, \mathrm{S}}}{F}
\end{aligned}
$$

これは $\tilde{\mu}_{\mathrm{e}}^{\mathrm{M}}$ と $\tilde{\mu}_{\mathrm{e}}^{\mathrm{S}}$ の差を電気量で割ったもの であり， $\mathrm{M}$ 中の自由電子を $\mathrm{S}$ へ持ち出すと きの仕事を電位に換算した值に相当します。 この值も, 原理的には実測可能ですが, エネ ルギーの基準点が溶液のバルクとなってお

り, $\mu_{\mathrm{e}}^{\circ \mathrm{S}}$ が溶液中の電子, すなわち溶媒和電 子を想定しているため, 水溶液系を含むほと んどの実験系で測定が困難です。そのため $E_{\mathrm{abs}, 2}$ もほとんど用いられません。

3 つめの定義は,

$$
\begin{aligned}
E_{\mathrm{abs}, 3} & =E_{\text {sing }}+\chi^{\mathrm{S}} \\
& =\phi^{\mathrm{M}}-\phi^{\mathrm{S}}-\frac{\mu_{\mathrm{e}}^{\circ, \mathrm{M}}}{F}+\chi^{\mathrm{S}}
\end{aligned}
$$

です。ここで $\chi^{\mathrm{S}}$ は $\mathrm{S}$ の表面電位，すなわち

$$
\chi^{\mathrm{S}}=\phi^{\mathrm{S}}-\psi^{\mathrm{S}}
$$

です。 $E_{\mathrm{abs}, 3}$ は $\mathrm{M}$ 中の自由電子を $\mathrm{S}$ の外側の 気相へ持ち出すときの仕事を電位に換算し たものです。言い換えれば, 電位に換算した $\mathrm{M}$ の仕事関数と, $\mathrm{M}$ と $\mathrm{S}$ の外部電位差との 和, すなわち

$$
E_{\mathrm{abs}, 3}=\frac{W^{\mathrm{M}}}{e}+\psi^{\mathrm{M}}-\psi^{\mathrm{s}}
$$

なので, 実測可能です。具体的には, 空気の 層を含む電気化学セルを用いた, ボルタ電位 差(Volta potential difference)測定により得る ことができます7)。

以上より，3 種類の絶対電極電位のうち, 使い物になったのは $E_{\mathrm{abs}, 3}$ だけなので, 何の 断りもなく単に「絶対電極電位」と言つた場 合は,この $E_{\mathrm{abs}, 3}$ を意味します。S. Trasatti は, 信頼できる実験結果に基づき, 標準水素電極 (SHE)の絶対電極電位を $25^{\circ} \mathrm{C}$ で

$$
E_{\mathrm{abs}}^{\circ}(\mathrm{SHE})=4.44 \pm 0.02 \mathrm{~V}
$$

と決定しました ${ }^{5)}$ 。SHE 基準で表された従来 の電極電位は， $4.44 \mathrm{~V}$ を足すことにより，簡 単に絶対電極電位に書き換えることができ ます。

このように絶対電極電位を用いれば, 参照 電極によらず, 電極の物理化学的性質に基づ いて電極電位を表すことができますが，この
$4.44 \mathrm{~V}$ （乾電池 3 個分?）などといった值が 実際のところ何の電位を表しているのか, 意 味がちよっとわかりにくいと思います。この わかりにくさはどこから来ているかという と, 電気化学ポテンシャルから静電エネルギ 一の寄与を引いた項である化学ポテンシャ ル $\mu_{\mathrm{e}}^{\circ, \mathrm{M}}$ までひっくるめて電位に換算してし まっていることによります。本来これは, 静 電エネルギーではないので, 電気量で割って 電位に換算すべきものではありません。この ために上記 3 種類の絶対電極電位はいずれ も，どこかとどこかの 2 点間の電位差，とい う静電学的にわかりやすい意味を持たなく なってしまっています。つまり電位の空間分 布を電位プロファイルとして表現できない, 仮想的な量です。あくまでも個人的な見解で すが, 私には絶対電極電位のコンセプト自体 がアイデア倒れのように感じられます。（実 際, 最近の文献ではあまりお目にかかりませ ん。）もともとの物理化学的意味に立ち戻っ て考えれば，これらの量はいずれも，仕事関 数と同様に，化学的なエネルギーも含めた 2 点間の電子のエネルギー差に基づいている ので, 電位 $(\mathrm{V})$ ではなくエネルギー $(\mathrm{eV})$ の単 位で表すべき量であり，W. H. Hansen らのよ うに「半電池の仕事関数(work function of a half-cell)」 ${ }^{8)}$ と呼ぶのが妥当と思います。

1) 巽 広輔, Rev. Polarogr., 64, 106 (2018).

2) 本文中 $E_{\sigma=0}$ で表した電位を $E_{\mathrm{pzc}}$ と表すこ ともありますが，ここでは Parsons の書き方 に従いました ${ }^{3)}$ 。

3) R. Parsons, Pure Appl. Chem., 37, 501 (1974).

4) 巽広輔, Rev. Polarogr., 64, 27 (2018).

5) S. Trasatti, Pure Appl. Chem., 58, 955 (1986).

6) これとは別に「酸化還元系の Fermi 準位」 （ $\tilde{\mu}_{\mathrm{e}}^{\mathrm{S}}$ とは異なるので注意！）というものも 定義すれば, $E_{\mathrm{abs}, 1}$ を用いて酸化還元平衡を記 述できます。おもしろい考え方ですが，あま り一般的ではありません。（日本化学会編, 分子レベルからみた界面の電気化学, 学会 出版センター (1975) 第 1 章などを参照) 7) 玉虫 伶太, 電気化学 (第 2 版), 東京化 学同人 (1991) 第 1 章.

8) W. N. Hansen and K. B. Johnson, Surf. Sci., 316, 373 (1994).

（信州大学理学部 巽 広輔） 


\section{2. フェロセンデンドリマーのサイクリックボルタモグラム}

質問 図 1 のデンドリマーには，8つの等価なフェロセン部位 $(\mathrm{Fc})$ があります.この化合物の サイクリックボルタモグラム $(\mathrm{CV})$ は図 2 のように 2 段波になることが報告されています [1]. このような形になる理由を教えてください.

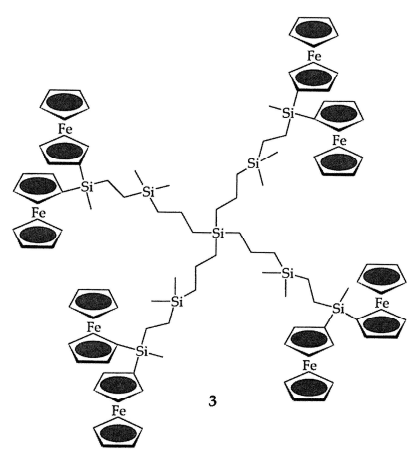

図 1 Fc デンドリマーの構造

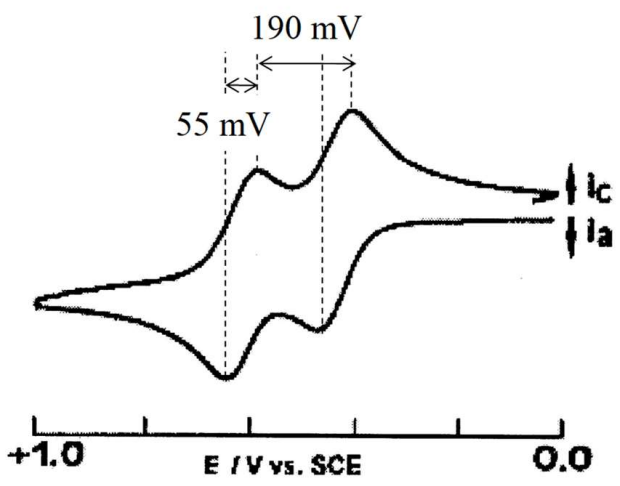

図 $2 \mathrm{Fc}$ デンドリマーの $\mathrm{CV} . \mathrm{CH}_{2} \mathrm{Cl}_{2} / \mathrm{CH}_{3} \mathrm{CN}(5: 1)$,

$0.1 \mathrm{M}$ TBAH, Pt 電極, $v=100 \mathrm{mV} \mathrm{s}^{-1}$.

\section{解説}

第 1 波の酸化還元電位は $E^{\circ}{ }_{1}=0.41 \mathrm{~V}$ (vs. SCE)で, 第 2 波の酸化還元電位は $E^{\circ}{ }_{2}=0.60 \mathrm{~V}$ です．ピークセパレーションはどちらも $55 \mathrm{mV}$ で，ピーク波高から各過程の全電子数もお互 いに等しいことが想定できます.もともと 8 つ等価な Fe がありますが，4つに枝分かれし た 2 対の $\mathrm{Fc}$ が存在することから, 対の一方の $\mathrm{Fc}\left(\mathrm{Fc}_{1}\right)$ が計 4 つ酸化され第 1 波を形成し, $\mathrm{Fc}_{1}$ に隣接する $\mathrm{Fc}\left(\mathrm{Fc}_{2}\right)$ が計 4 つ酸化され第 2 波を形成することが考えられます．しかしな がら，この CV の波形からいろいろ面白いことがわかります。

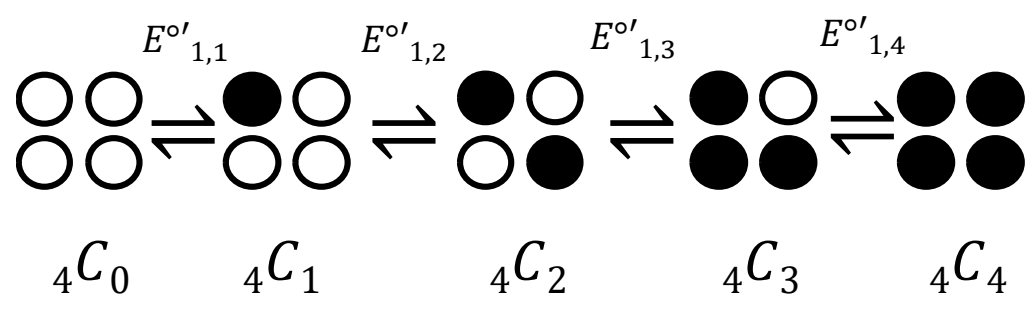

図 34 段階 1 電子反応の説明図 下はその状態の数を表す. 
第 1 波の過程で, 4 つの $\mathrm{Fc}_{1}$ が 1 段階 4 電子酸化されるとすると, ピークセパレーションは 拡散可逆過程であるとするなら約 $2.3 R T /(4 F) \approx 15 \mathrm{mV}\left(25^{\circ} \mathrm{C}\right)$ となるはすです.しかし，実 測值は $55 \mathrm{mV}$ で，(論文では測定温度が不明ですが）電子数 $n=1$ の波形となっています。し たがって，この過程は 4 段階 1 電子反応であると結論できます.

ここではさらに，第 1 波の 4 つの巨視的な酸化還元電位 $E^{\circ \prime}{ }_{1, j}$ について考えます. 4 つの $\mathrm{Fc}_{1}$ は等価でお互いに十分離れており，相互作用しないと仮定し，図 3 のように 4 段階 1 電子 反応すると考えます．このとき，ひとつの $\mathrm{Fc}_{1}$ サイトの微視的な酸化還元平衡のネルンスト 式（1つのサイトだけを考えるとこれは確率論的なものを表す式に相当します）は次のよう に与えられるとします。

$$
\frac{\left[\mathrm{Fc}^{+}\right]}{[\mathrm{Fc}]}=\exp \left[\frac{F\left(E-E^{\circ}{ }_{1}\right)}{R T}\right]
$$

第 1 波の 4 電子酸化の $j$ 段目の巨視的な酸化還元平衡とは $j$ 個のフェロセニウム部位 $\mathrm{Fc}_{1}{ }^{+}$ がある酸化状態と, $(j-1)$ 個の $\mathrm{Fc}_{1}{ }^{+}$がある還元状態間の平衡です. $j$ 個の $\mathrm{Fc}_{1}{ }^{+}$がある状態の 数は図 3 に示すように ${ }_{4} C_{j}$ 個ですから, $j$ 段目の巨視的な酸化還元平衡のネルンスト式は次の ように与えられます。

$$
\frac{{ }_{4} C_{j}\left[\mathrm{Fc}^{+}\right]}{{ }_{4} C_{j-1}[\mathrm{Fc}]}=\frac{(5-j)}{j} \frac{\left[\mathrm{Fc}^{+}\right]}{[\mathrm{Fc}]}=\exp \left[\frac{F\left(E-E^{\circ \prime}{ }_{1, j}\right)}{R T}\right]
$$

式(1), 式(2)より

$$
E_{1, j}^{\circ}=E_{1}^{\circ}+\frac{R T}{F} \ln \left(\frac{j}{5-j}\right)
$$

と得られます.つまり $E^{\circ}{ }_{1} \pm 35.6 \mathrm{mV}$ と $E^{\circ}{ }_{1} \pm 10.4 \mathrm{mV}\left(25^{\circ} \mathrm{C}\right)$ の 4 つの $n=1$ の CV が重なっ て, ひとつのピークを与えることになり, 重なり合った CV は $n=1$ で濃度だけが 4 倍とな った波形となるのです.

等価な部位が $m$ 個あるときの一般式は次のように与えられます.

$$
E_{j}^{\circ \prime}=E^{\circ}+\frac{R T}{F} \ln \left(\frac{j}{m-j+1}\right)
$$

このとき，

$$
E^{\circ}=\sum E^{\circ \prime}{ }_{j} / m
$$

と与えられます．等価なサイトをもつ多電子過程の可逆 CV のピークセパレーションが $n=1$ の挙動であれば，そのサイト間はお互いに相互作用なく，巨視的な酸化還元電は式(4)のよう に分布します.一方，ピークセパレーションが $n=1$ の場合より狭ければサイト間に引力があ ることを示しています．逆に，第 1 波と第 2 波のピークセパレーションのように, $n=1$ の場 合より広ければサイト間に斥力があることを示しています.

8 つのうち，5つめの $\mathrm{Fc}\left(\mathrm{Fc}_{2}\right)$ を酸化しようとすると，隣接する $\mathrm{Fc}_{1}$ はすでに $\mathrm{Fc}_{1}{ }^{+}$に酸化され ていますから, クーロン反発が起こります. 隣接する $\mathrm{Fc}_{1}$ と $\mathrm{Fc}_{2}$ の距離 $r$ を $5 \AA$ とし, 混合溶 媒の比誘電率 $\varepsilon_{\mathrm{r}}$ を加成計算して求めると, $\varepsilon_{\mathrm{r}}=10.4 \times 5 / 6+37.5 \times 1 / 6=15$ となるので, $\mathrm{Fc}^{+}$ 
から $r$ 離れた静電ポテンシャル $E$ は次のように与えられます.

$$
\begin{aligned}
E=\frac{e}{4 \pi r \varepsilon_{\mathrm{r}} \varepsilon_{0}}= & \frac{1.602 \times 10^{-19} \mathrm{C}}{4 \times 3.14 \times\left(5 \times 10^{10} \mathrm{~m}\right) \times 15 \times\left(8.854 \times 10^{-12} \mathrm{~F} \mathrm{~m}^{-1}\right)} \\
& =0.19 \mathrm{~V}
\end{aligned}
$$

つまり，この隣接クーロン反発により，第 2 波は $0.19 \mathrm{~V}$ だけ正の電位で観測されることにな ります. 6 電子目から 8 電子目も同様のことが起こります.これは実験值とよく一致します. 2 段目の波がほぼ $n=1$ の波形となったことは，4つの $\mathrm{Fc}_{2}{ }^{+}$間は十分離れているので，静電相 互作用が無視できたと結論することができます.

[1] I. Cuadrado, C. M. Casado, B. Alonso, M. Morán, J. Losada, and V. Belsky, J.Am.Chem. Soc., 119, 7613-7614 (1997) 加納健司（京都大学農学研究科）

「電気分析化学, ここが難しい」シリーズに

投稿、意見，回答をお待ちしています！

1. 電気化学の理論, 測定法, ボルタモグラムの解釈など，種々の疑問を受け付けます。

2. 教科書に書かれている，または，定説となっている電気化学の理論，実験についての

「新しい解釈」「新規アプローチ」の提案も歓迎します。

3. 初心者が陥りがちな間違い, 誤解を解決してくれるような, テキストには書かれないノ ウハウの披露も歓迎します。

4.これまでに掲載された「ここが難しい」の記事についての質問, 反論, 回答などを歓迎 します。

$$
\text { <本シリーズへの投稿方法 }>
$$

編集委員長あるいは企画担当の編集委員にメールでお送りください。体裁は問いません。 投稿いただいた内容は，編集委員会で検討の上，本誌の「ここが難しい」コーナーに随時掲 載いたします。

本学会のウェブ掲示板 (http://6219.teacup.com/polarography/bbs) に投稿してくださっても結 構です。匿名希望の場合はイニシャルをつけてください。

$$
\text { （本シリーズ担当編集委員 山本雅博） }
$$




\section{電気分析化学，ここが難しい！Part 4}

\section{3. 電気化学反応速度は遷移状態理論？それとも LFER? (1)}

いわゆる Butler-Volmer（より正確には Butler, Erdey-Grúz, Volmer) 理論が電気化 学反応速度論の基礎理論であるが, それは 生成物の状態を考えない遷移状態理論で 一見説明できるように思える。実際にその ように説明されていることも多いが, 果た してそうであろうか?ここでは, 現在の反 応速度論の状況についてレビューして, 上 の問いに対する解答を行いたい。

反応速度論であるが, 物理化学的な視点 からはどのように見られているのは,マッ カリ・サイモンの「物理化学」に以下のよ

\section{うな記述がある。}

Our development of chemical kinetics will differ from our presentation of quantum mechanics and thermodynamics. In developing quantum mechanics, we started with a small set of postulates, and classical thermodynamics is built upon just three laws. If we had our choice, we would certainly develop chemical kinetics starting with a few very simple principles. Unfortunately, this is not yet possible. The field of chemical kinetics has not yet matured to a point where a set of unifying principles has been identified, but the current search for such a set contributes to the excitement of modem research in the field.

Presently, there are many different theoretical models for describing how chemical reactions occur. None is perfect, but each has its merits. Several provide a microscopic picture of how chemical reactions take place. Thus, in chemical kinetics, you must become familiar with different ideas and sometimes concepts that seem unrelated. Bear in mind that this situation is common in scientific disciplines in which further research is needed in order to provide a more fundamental understanding of the subject. (註 : 斜体は筆者が加工した)

反応速度論の中核をなす遷移状態理論は, 反応物と遷移状態にある活性化錯合体が部 分平衡にあり, 遷移状態にある活性化錯合体 の一部がある一定の割合で生成物になって いくという考え方を採用している。部分平衡 のところで, 統計力学の分配関数をつかうと, たとえば金属中の水素と重水素の拡散定数 の同位体効果が非常によく説明できる[2]。 遷移状態理論では, 遷移状態を超えればエネ ルギーの坂をころがって生成物に到達する はずであるが, 場合によっては遷移状態にあ るいは反応物に戻ってくることがある (再交 差）。これは分子振動が励起した状態では必 ずしも遷移状態が鞍点になってないことに 起因するが，よほど高温でなければそれほど 大きな問題にはならない。また，低温では， トンネル効果により障壁を越えることなし に反応物から生成物に移動できる場合もあ る。一般にこの効果は活性化障壁を乗り越え ることが困難になってくる低温できいてく るが, 量子的な性質をもつ電子が移動する電 子移動反応の場合は常温でも考慮されてい い。以上のような標準理論となっている遷移 状態理論であるが, 溶液中の反応や溶液中の 電子移動反応ではどう扱われているのだろ 
うか?

溶液中の反応速度では, 物質移動が問題に なることが当然予想される。特に溶液の粘度 $\eta$ が高い場合に遷移状態理論になんらかの 修正が必要になるのであろうか?この問題 は Kramers らによって，粘性を考慮したラ ンジュバン方程式の解析により求められて いる。粘度 $\eta$ が高いときは, 反応速度の透 過係数にその効果はあらわれ粘度に反比例 するが, 粘度が小さいときは速度定数はむし ろ粘度に比例して増加することが理論的に 示唆された。速度定数は粘度とともに増加す るがその後減少に転ずるという Kramers の 反転が実験的にも確かめられている。[3] 溶液中の電子移動反応の基礎は Marcus 理 論である。それを電極上での redox 反応に 拡張したのは Gerischerであるが, 電子を固 体のバンドとみなした以外は基本的な考え 方は Marcus の考え方と変わっていないと していい。

通常の化学反応では結合の組み替えを伴う ので, ある化学結合に関する空間座標をとれ ばそれを反応座標とみなしていいが, 電子移 動では, 電子の移動前後で化学結合の組み替 えがおきないことが多いため, 定義が容易で ない。しかし，理論的には例えば redox 対 間での電荷移動の進行度（1電子移動なら0 から1の值をとる。いわば無次元の反応進行
度である）をとれば明確に定義できる。 Redox 対の電荷（電子状態）が大きく変化 寸るので, 周りの溶媒分子の溶媒和環境が大 きく変化する。反応経路 (電荷移行の進行度) の違いによって，それぞれの redox 体がど のような自由エネルギー曲線を描くのかは, Marcus は古典的な誘電体論をつかって放物 線上になることを示した。最近では，古典的 な分子動力学シュミーレーション [4] や積 分方程式論 [5] を用いても放物線上になる ことが示されているのでこの溶媒和の変化 に伴う自由エネルギー曲線が電子移動の反 応速度を決定することになる。 (次回に続く)

\section{参考文献}

[1] (a) J. A. V. Butler. Trans. Faraday Soc. 19, 729 (1924); (b) J. A. V. Butler. Trans. Faraday Soc. 19, 734 (1924). [2] T. Erdey-Gruz, M. Volmer. Z. Physik. Chem. A 150, 203 (1930). [2] Naito, S.; Yamamoto, M.; Doi, M.; Kimura, M. J. Electrochem. Soc., 145, 2471-2475(1998). [3]大学院講義物理化学 II 反応速度とダイナミックス II [4] C. Hartnig, M. Koper, J. Chem. Phys. 115, 8540 (2001) [5] H. Sato, F. Hirata, J. Phys. Chem. A, 106,2300-2304(2002)

(甲南大学理工学部 山本雅博) 